\title{
A Micronized Electrostatic Precipitator Respirator Effectively Removes Ambient SARS- CoV-2 Bioaerosols
}

Rachel K. Redmann ${ }^{1, \#}$, Brandon J. Beddingfield ${ }^{1, \#}$, Skye Spencer ${ }^{1}$, Nicole R. Chirichella ${ }^{1}$, Julian L. Henley ${ }^{3,4}$, Wes Hager ${ }^{5}$, Chad J. Roy ${ }^{1,2 *}$

${ }^{1}$ Infectious Disease Aerobiology, Division of Microbiology, Tulane National Primate Research Center, Covington, LA 70433

${ }^{2}$ Department of Microbiology and Immunology, Tulane School of Medicine, New Orleans, LA 70112

${ }^{3}$ Section of Otolaryngology, Yale-New Haven Hospital, New Haven, CT 06520

${ }^{4}$ Henley Ion, New Orleans, LA 70115

${ }^{5}$ Phase Three Product Development, Fort Collins, CO 80526

\# these authors contributed equally to this work. 
Rationale: Inhalation of ambient SARS-CoV-2-containing bioaerosols leads to infection and pandemic airborne transmission in susceptible populations. Filter-based respirators effectively reduce exposure but complicate normal respiration through breathing zone pressure differential and are therefore impractical for long-term use.

Objectives: We tested the comparative effectiveness of a prototyped micronized electrostatic precipitator (mEP) to a filter-based respirator (N95) in the removal of viral bioaerosols from a simulated inspired air stream.

Methods: Each respirator was tested within a 16-liter environmental chamber housed within a Class III biological safety cabinet within biosafety level 3 containment. SARS-CoV-2 containing bioaerosols were generated into the chamber, drawn by vacuum through each respirator, and physical particle removal and viral genomic RNA were measured distal to the breathing zone of each device.

Measurement and Main Results: The mEP respirator removed particles $(96.5 \pm 0.4 \%)$ approximating efficiencies of the N95 $(96.9 \pm 0.6 \%)$. The mEP respirator similarly decreased SARS-CoV-2 viral RNA (99.792\%) when compared to N95 removal (99.942\%) as a function of particle removal from the airstream distal to the breathing zone of each respirator.

Conclusions: The mEP respirator approximated performance of a filter-based N95 respirator for particle removal and viral RNA as a constituent of the SARS-CoV-2 bioaerosols generated for this evaluation. In practice, the mEP respirator would provide equivalent protection from ambient infectious bioaerosols as the N95 respirator without undue pressure drop to the wearer, thereby facilitating long-term use in an unobstructed breathing configuration.

Key Words: SARS-CoV-2, bioaerosols, electrostatic precipitation, respiratory protection 
medRxiv preprint doi: https://doi.org/10.1101/2022.01.27.22269961; this version posted January 28, 2022. The copyright holder for this preprint

(which was not certified by peer review) is the author/funder, who has granted medRxiv a license to display the preprint in perpetuity.

It is made available under a CC-BY-ND 4.0 International license .

Author contributions: C.J.R., J.L.H., and R.K.R. designed the study and prepared the protocol.

R.K.R., B.J.B., W.H., S.S., and N.R.C. performed the studies, and assisted with data collection.

B.J.B., R.K.R., and C.J.R. performed statistical analyses and prepared figures. C.J.R., B.J.B, and

J.L.H. wrote and edited the manuscript.

Correspondence and requests for reprints should be addressed to Chad J. Roy, Ph.D., Division of

Microbiology, Tulane National Primate Research Center, 18703 Three Rivers Road, Covington,

LA 70433. E-mail: croy@tulane.edu 


\section{Introduction}

SARS-CoV-2 is a pathogenic beta-coronavirus that is the source of a current worldwide pandemic [1]. The virus has thus far proved to be highly transmissible and passes easily via respiratory droplet between the shedding infectious to naïve host [2]. The combination of inability to readily kill immunocompetent hosts, but rather use the respiratory system as an efficient vectoring pathway to infect others has made the resultant disease (COVID-19) one of the most prolific in human history, infecting hundreds of millions, and killing $>5$ million worldwide [3]. There has been a sustained surge in the use of respiratory protection throughout all sectors of society to effectively reduce ambient exposure and avoid infection [4-6]. The majority of the public currently use facial coverings consisting of cloth or 'surgical' masks, which provide protection only to others proximal to the wearer of the cloth mask [7-9]. The mechanism of particle collection for cloth masking is through microburst high velocity exhalation of the wearer and subsequent impaction upon inside surface of the mask [10]. Although essentially no protection from ambient bioaerosols is provided when donning cloth/surgical masks, current public health mandates during the pandemic require the use of cloth/surgical masking by the public to further reduce community disease burden by retarding respiratory transmission at the source generator (the infected wearer). Some among the public and most healthcare professionals have chosen to don filter-based respirators which, unlike cloth masks, provide respiratory protection from ambient bioaerosols through impaction and interception collection on a thermospun/cellulose filter substrate [11]. The most popular of filter-based respirators is the nonoil-95 percent collection (N95) filter-based respirator. For filter respirators to properly function, inspired air is required to pass through the face of the filter 
respirator and pass through a tortuous matrix of the substrate before reaching the breathing zone of the wearer $[12,13]$. Particle collection by the filter respirator is also contingent upon a nearly airtight seal on the face of the wearer $[14,15]$. This configuration in properly donned filter respirators produces a significant pressure drop $\left(\sim 0.27 \Delta \mathrm{P} \mathrm{cm} \mathrm{H}_{2} 0\right)$ between ambient air and the breathing zone upon inspiration. While providing sufficient protection against particles of a particular size ( $>0.3 \mu \mathrm{m}$ non-oily aerosols), this pressure drop can become noticeable and laborious during longer-term use in otherwise healthy users and may become obstructive in individuals with compromised respiratory systems.

Particle collection by electrostatic precipitation (EP) has been used successfully in industrial applications for decades [16], although application of the technology for the purposes of personal respiratory protection has historically not been pursued, with few exceptions at harnessing a form of EP on a micronized scale for personal protection [17-20]. The principle of EP provides for removal of particles from an airstream based upon coronal discharge of electrons onto an opposite charged collection plate. The efficiency by which this mechanism collects airborne particles is correlative to the amount of energy provided to the corona, transit time, distance, and corresponding flow rate of the targeted airstream. Most commercially available ionizer-based devices use a corona discharge emitter creating an excess of ions and electrons interposed into the airflow followed by collector plates separated by a specific distance and electric field density between them. The airborne incidental particles and aerosol acquire a charge and then are deposited upon the collector plate and diverted from its intended path. Most of those designs have unidirectional functionality [17] and often have supportive fans to maintain the desired air flow past the corona discharge and between the collector plates needed to remove the particles 
from the air flow path. In this application, an EP was micronized (mEP) and engineered to collect particles from the uninterrupted respiratory airstreams of the wearer. This design also relies upon natural velocities of normal inspiratory and expiratory flow to generate the airflows required to bring functionality to the device. The resulting mEP respirator functions as an energized particle collector without any appreciable pressure drop between ambient air and the breathing zone of the wearer because the mechanism of particle collection is not filtration, a mechanism which requires wearer inspiratory flow to actively pull and push air through a filter substrate. A prototype of the mEP respirator was engineered to be self-contained and worn in a similar configuration that approximates the face fit and head strapping design of popular filterbased respirators.

In this study, we tested the particle collection efficiencies of the prototyped mEP respirator and compared performance with a N95 filter respirator, and an in-line HEPA cartridge filter. Each of the devices were tested using a modified 16-liter chamber operated in a dynamic configuration within high (BSL-3) biocontainment [21]. An atmosphere of viral bioaerosols were synthetically generated and maintained in the chamber during testing of each device. After fully characterizing the particle concentration, airborne viral titer, and corresponding counts within the ambient environment of the chamber, we measured the collection efficiency of each device. Once configured into the chamber, each respirator was sealed in such a way to only collect airstream contents distal to the inlet face or 'breathing zone' upon inspiration. Total particle counts were performed initially to determine particle reduction from each device. Thereafter, aerosol samples were collected from the airstream in the same configuration and 
analyzed for culturable virus by $\mathrm{TCID}_{50}$ and genomic RNA content as a surrogate for viral capture as a constituent of the bioaerosols collected by each respirator.

\section{Materials and methods}

2.1 Design and operational principles of the $\mathrm{mEP}$ respirator

The prototype device (Figure 1a) is designed to fit on the face of the user and is held to the face through the use of strapping on the back of the head. The prototype device was designed to minimize the corona discharge by setting the operational point and controlling such with an embedded CPU control of the emitter voltage (Figure $1 \mathrm{~b}$ and $1 \mathrm{c}$ ) so that effective particle reduction can occur within the specified geometry and very little corona discharge, or ozone formation, is encountered. This servomechanism maintains performance at the set point despite ambient temperature, humidity, or site elevation. It is therefore advantageous to maintain control of the ionization process and assure its performance under different circumstances and elevations. The same servomechanisms allow for fine control of ozone $\left(\mathrm{O}_{3}\right)$ production with or without a catalytic degradation filter.

\subsection{Benchmark Testing of the mEP for particle removal}

Preliminary testing of particle removal capacity of the mEP was performed using aerosolized salt solution at high inlet flow (85 liters per minute (LPM)). Briefly, an aerosol particle generator (Model 8026 Particle Generator, TSI Systems, St. Paul, MN) loaded with 
saline solution was connected to a test chamber via tubing and passed through honeycomb to facilitate laminar flow through the chamber that housed the device and the samplers. A regenerative blower (VFC 080P-5T, Fuji Electric, Edison, NJ) was used to create airflow (85 LPM; 16" $\mathrm{H}_{2} 0$ ) through the mEP device while housed in the chamber. Flow through the mEP was monitored during this assessment (SFM3000 Mass Flow Meter, Sensirion AG, Stäfa, Switzerland). Particle counts were measured distal to the inlet of the mEP using an optical particle counter (Model 8525, TSI). Ozone concentration was also measured using an ozone measurement device (FD-90A-O3 Forensics Detectors, Estates, CA). Power requirements to the $\mathrm{mEP}$ device during this preliminary assessment were both supplied to the device and measured (using a multimeter) in relation to the active particle removal and ozone measurements. Results showed (Fig. 1d) that a $\sim 0.35$ milliwatts (mw) power selection resulted in a particle collection of $\sim 95 \%$. The results of time series experiments using longer operational durations indicated that particle rejection slightly improved to $\sim 97.5 \%$, suggesting relatively stable particle collection over extended wear times (data not shown). Similarly, $\mathrm{O}_{3}$ levels generated by the device (Fig. 1e) were below U.S. Occupational Safety and Health Administration (OSHA) limits of $<0.1$ parts per million (ppm) and at selected power level of $0.35 \mathrm{mw}, \mathrm{O}_{3}$ levels remained below U.S. Food and Drug Administration (FDA) limits of $<0.05 \mathrm{ppm}$. The results of the saline aerosol particle removal testing ensured operational functionality and for the subsequent evaluation involving SARS-CoV-2-containing bioaerosols performed within biocontainment. Performing benchmark testing using harmless saline aerosols also allowed measurement of $\mathrm{O}_{3}$ (which was not measured in biocontainment), and optimized mEP power setting for removal of viral bioaerosols when the device was used in containment. 
2.6 Experimental airborne viral removal efficiency

\section{Experimental Configuration}

Use of standard mask evaluation methodology (e.g., 42 CFR Part 84)[22] was not feasible to the experimental approach as SARS-CoV-2 aerosolization required additional engineering controls, including housing our configuration within a Class III biological Safety cabinet, for added safety during these studies because of the biologically active nature of the virus and the necessity of biosafety level 3 (BSL-3) containment. Therefore, all SARS-CoV-2 aerosol generation took place inside a 16-liter polycarbonate chamber outfitted with dilution and exhaust tubing and a sampling orifice. The chamber was connected to an automated system (Biaera Technologies, Hagerstown, MD) which controlled dilution, exhaust, sampling, and generator air flows when applicable, and also recorded temperature, relative humidity, and pressure readings. The automated system maintained equal rates of total air flow in and out of the chamber in order to retain equilibrium. Figure 2 illustrates the experimental configuration of the chamber utilizing the $\mathrm{mEP}$ respirator and the various sampling strategies implemented within biocontainment. The aerosol generator (Fig. 2, A) used was the 3-jet (3JC) collision nebulizer. Samples from the chamber (Fig. 2, C) were collected using either the APS for particle counting (Fig. 2 D) or the all glass impinger (Fig. 2, E) sampler for virus collection. Total air flow in and out of the system was maintained at 16 LPM, with adjustments to the dilution (Fig. 2 B) and exhaust flows (Fig. 2 F) as needed for differing generator and sampling requirements, facilitated through the use of the automated aerosol control system (Biaera).

\section{Experimental Procedure}


Individual aliquots of a liquid volume (5 ml) of SARS-CoV-2 inoculum and corresponding dilutions were prepared for evaluation of each respirator. Upon performance for each respirator, a liquid aliquot was directly expressed into the precious fluid reservoir for the Collison nebulizer and then actuated and allowed to continuously run for analysis. The experimental configuration was harmonized amongst both respirators and shared similar design and internal volume (Fig. 1). Flow rates for the configured system was maintained at 16 LPM. Two aerosol sampling instruments with differing flows were used in each discrete aerosol generation event. For the experiments involving particle counting, the aerodynamic particle sizer (Model 3321, TSI) was used which houses an internal exhaust flow of 5 LPM. Residual exhaust flow was provided via an external pump at 2 LPM. SARS-CoV-2 aerosols were also collected in separate aerosol generation events for the purposes of biological viability determination of the viral aerosols. Individual all glass impingers (AGI-4, SKC, Eighty-four, PA) were used to collect aerosol sample from either the ambient chamber or the flow distal to each respirator and was actuated upon initiation of each run of the aerosol system. The AGI-4 sampler requires 6 LPM exhaust flow for operation. The residual exhaust flow from the chamber was adjusted according to either sampling requirement and the necessity to maintain neutral pressure $\left(0\right.$ " $\left.\mathrm{H}_{2} 0\right)$ which was actively monitored throughout all aerosol generation events. The dynamic flows as described through the evaluation chamber were operated continuously for every evaluation for each respirator. Temperature and humidity were monitored continuously. The prevailing temperature was $20.4 \pm 3.6^{\circ} \mathrm{C}$ and relative humidity $57.6 \pm 7.2 \%$ across all evaluations. 
Particle characteristics, including particle counts, were determined using an aerodynamic particle sizer (APS Model 3321, TSI Inc., St. Paul, MN). The APS measures the aerodynamic size of particles from 0.5 - 20 microns and uses time-of-flight analysis based upon velocity and relative density of interrogated particle stream to determine particle behavior while airborne. Aerosol is drawn into the APS at a total flow of 5 LPM; $20 \%$ of the total flow is dedicated to inlet into the analyzer; $80 \%$ is sheath flow. The APS spectrometer uses a double-crest dual laser system and nozzle configuration which reduces the advent of false (e.g., doublet) background counts. Analysis of data from the APS was collected and device software (Aerosol Instrument Manager Version 5.3, TSI Inc., St Paul, MN) was used for initial review of data. The APS device operated on a continual basis once aerosol generation was initiated, and logged data for the duration of each aerosol event. Resulting particle size generated from the Collison nebulizer in this configuration yielded a mass median aerodynamic diameter of $2.1 \mu \mathrm{m}$ and geometric standard deviation of 1.4 .

\section{Virus and Cells}

Virus used for aerosol generation was strain SARS-CoV-2; 2019-nCoV/USA-WA1/2020 (BEI\# NR-52281) prepared on subconfluent VeroE6 cells (ATCC\# CRL-1586) and confirmed via sequencing. Vero E6 cells were used for live virus titration of sample input and were maintained in DMEM (\#11965092, Thermo Scientific, USA) with 10\% FBS.

\section{Quantification of Viral RNA in aerosol samples}

Viral RNA in collected aerosol samples was quantified using RT-qPCR targeting the nucleocapsid (genomic) of SARS- CoV-2. RNA was isolated from aerosol samples using a 
Zymo Quick RNA Viral Kit (\#R1035, Zymo, USA), per manufacturer's instructions. RNA was eluted in RNAse free water and was extracted using $100 \mu \mathrm{L}$ of sample. Isolated RNA was analyzed in a QuantStudio 6 (Thermo Scientific, USA) using TaqPath master mix (Thermo Scientific, USA) and appropriate primers/probes [23] with the following program: $25^{\circ} \mathrm{C}$ for 2 minutes, $50^{\circ} \mathrm{C}$ for 15 minutes, $95^{\circ} \mathrm{C}$ for 2 minutes followed by 40 cycles of $95^{\circ} \mathrm{C}$ for 3 seconds and $60^{\circ} \mathrm{C}$ for 30 seconds. Signals were compared to a standard curve generated using in vitro transcribed RNA of each sequence diluted from $10^{8}$ down to 10 copies. Positive controls consisted of SARS-CoV-2 infected VeroE6 cell lysate. Viral copies per sample were calculated by multiplying mean copies per well by amount in the total sample extract.

\section{Quantification of Culturable Virus}

Median Tissue Culture Infectious Dose $\left(\mathrm{TCID}_{50}\right)$ was used to quantify replicationcompetent virus in viral stock used to generate the aerosols used in the respirator evaluations. VeroE6 ells were plated in 48-well tissue culture treated plates to be subconfluent at time of assay. Cells were washed with serum free DMEM and virus from $50 \mu \mathrm{L}$ of sample was allowed to adsorb onto the cells for 1 hour at $37^{\circ} \mathrm{C}$ and $5 \% \mathrm{CO}_{2}$. After adsorption, cells were overlayed with DMEM containing 2\% FBS and 1\% Anti/Anti (\#15240062, Thermo Scientific, USA). Plates were incubated for 7-10 days before being observed for cytopathic effect (CPE). Any CPE observed relative to control wells was considered positive and used to calculate TCID $_{50}$ by the Reed and Muench method.

\section{Statistics}


All data from the evaluation studies that included particle counting and viral bioaerosol removal was assessed using Prism 9 (GraphPad Software, San Diego, CA). For both sets of data, a repeated measures ANOVA was performed with Geisser-Greenhouse correction and Tukey's multiple comparisons test. Significance was noted at $\mathrm{p}<0.05$.

\subsection{Results}

Results of the particle counting in the experiments involving viral bioaerosols showed a clear reduction in the number of particles reaching the distal portion of the mask when the powered mEP or N95 respirator was in place (Figure 3). A HEPA filter was used as a control mechanism to confirm particle counts would essentially zero when positioned to receive inspiratory flow. The mEP performed on approximately an equivalent basis as the N95 respirator, returning an average $96.5 \%$ particle removal as compared to the N95 which removed an average of $96.9 \%$ of particles at measured air flow velocities. There were no significant difference between the particle removal rates between the mEP and the N95 respirator. There were significant differences when ambient particle concentration was compared to the powered mEP, N95, or HEPA filter values.

The results of the viral bioaerosol evaluation indicated, as observed from the particle removal experiments, the mEP removed most all of the viral RNA from the airstream as measured by RT-PCR analysis of the distally-positioned aerosol sampler (Figure 4). When the mEP was de-energized (denoted in the legend as mEP 'OFF'), viral RNA approximated ambient levels expressed in SARS-CoV-2 genome copies/liter aerosol. Interestingly, percentage 
removal, when measured by viral RNA, was remarkably similar between the mEP (99.79\%), N95 (99.94\%), and the HEPA filter (99.99\%).

\section{Discussion}

SARS-CoV-2 is an emergent, highly transmissible coronavirus. It is the etiologic agent for COVID-19, and the source of an ongoing worldwide pandemic. Over 5.4 million people have died worldwide from COVID-19 to date, with more than 847,000 deaths in the United States alone. Infection is associated with highly heterogenous disease sequelae, ranging from completely asymptomatic to severe acute respiratory distress and death. During this pandemic, respiratory protection in the form of facial coverings and, at times, filter-based respirators have been promoted to curb viral transmission and mitigate disease impact. Here, we performed a preliminary evaluation of a respirator that utilizes micronized electrostatic precipitation (mEP) rather than filtration for aerosol particle removal from the breathing zone of the wearer. We demonstrate that the mEP-based respirator in this evaluation effectively removed laboratory generated SARS-CoV-2-laden aerosol particles from an airstream at a rate that approximates filter-based respirators. The $\mathrm{mEP}$ respirator achieved equivalent particle reduction without the pressure drop required of filter-based respirators such as the N95. These data underscore the prospect for use of the new technologies that rely upon an alternative mechanism of airborne particle removal from the airstream than substrate-based filtration.

\subsection{Significance}


In this study we used a mEP respirator specifically designed to remove aerosol particles from the airstream at a rate associated with normal human respiration. The respirator was engineered to remove airstream particles during both inhalation and exhalation, although studies in this evaluation only sampled and measured inspiratory flow. The mEP respirator removed aerosol particles as demonstrated by the reduction of particle counts and the particle counter configured distal to the ambient air inlet and functional $\mathrm{mEP}$ within the respirator. The measurement of viral removal as a correlative of the physical particle removal was measured in the liquid impingement samples also collected distal to the respirator inlet and mEP device. The viral concentration of the ambient air surrounding the respirator was also sampled by liquid impingement for the purposes of residual comparison. The viral content of these liquid samples was measured by Median Tissue Culture Infectious Dose (TCID 50 ) and quantitative RT-PCR. The resulting culturable concentration of SARS-CoV-2 in the ambient air in the exposure chamber averaged $3.4 \mathrm{E}+3 \mathrm{TCID}_{50} /$ liter, or $9.7 \mathrm{E}+5$ genome copies/liter of aerosol. The $\mathrm{TCID}_{50}$ measurements of all liquid impinger samples distal to the mEP respirator inlet and the N95 respirator were nondetectable. This was due in part to the poor sensitivity of the $\mathrm{TCID}_{50}$ assay and the use of the cell culture to attempt to quantify low titer virus. Fortunately, all impinger samples were split after collection and processed for analysis of genomic content by RT-PCR. The results of this sampling showed an approximately equivalent removal of genomic material by the mEP and the N95 respirator under a similar laboratory configuration. Reduction of SARS-CoV-2 genomic content by either method was highly correlative with the physical particle removal resulting from particle counter measurements. Liberated SARS-CoV-2 virions $(\approx 110$ $\mathrm{nm}$ ) are componentry of biological aerosol particles and will not travel in the air alone but as a 
medRxiv preprint doi: https://doi.org/10.1101/2022.01.27.22269961; this version posted January 28, 2022. The copyright holder for this preprint (which was not certified by peer review) is the author/funder, who has granted medRxiv a license to display the preprint in perpetuity.

It is made available under a CC-BY-ND 4.0 International license .

component of a larger particle. In this case, aerosol particles generated in this evaluation were $\approx 2 \mu \mathrm{m}$ thus any SARS-CoV-2 virions would have inhabited the particles removed by the mEP.

\subsection{Limitations}

There are several limitations in the preliminary evaluation study performed on the $\mathrm{mEP}$ respirator as the generation of SARS-CoV-2 bioaerosols necessitated the use high containment (biosafety level 3) laboratory environment and unique aerobiology facilities configured for studies with high consequence pathogens and not necessarily respirator efficacy testing. The configuration conventionally used to test efficacy (NIOSH standard 42 CFR 84 also referred to as "Part 84 ") requires the use of high flow input ( $\approx 85$ LPM) as inlet flow across the face of the filter substrate being tested for removal efficiency. The high flow simulates pressure drop associated with the velocity of inspiration experienced by the user when breathing through a filter-based respirator. The $\mathrm{mEP}$ respirator is configured whereas there is near inperceptable pressure drop upon inspiration, thus there is no utility for the use of high flows for the purposes of evaluation. Rather, the inlet flows used in this evaluation approached but did not exceed 6 LPM during the studies. The disparity between the flowrates used in the NIOSH testing and this evaluation can be considered a weakness of the study. Similarly, although the mEP and the N95 respirators were tested under the inspiration configuration (6 LPM either across the filter substrate of the N95 or through the inlet of the mEP), neither respirator was tested for efficacy for particle removal efficacy upon expiration. Although the mEP respirator will theoretically remove particles upon expiration, this evaluation study does not include a demonstration of the technology performing in this manner and should be one of the aspects of future evaluation studies. 
Viral bioaerosols removed from the inspiratory airstream accumulate on the collector plates of the mEP respirator within the device. There was no analysis to determine the viability of the virus collected on the mEP plates. The particle removal efficacy studies did not include a hygiene protocol to elute collected aerosol particles from the collector plates once removal had taken place. Theoretically a virus captured in this manner (electrostatically) would dehydrate and be rendered inactive, and although this study did not include a laboratory demonstration of this effect, previous studies using electrically-charged surfaces illustrate the capacity for deactivation of virus [24]. Similarly, the mEP respirator required a continuous power source for functionality and performance, and although airflow is not restricted when the mEP unit is not powered, the benefits of particle removal dissipate. When powered, the mEP unit within the respirator generates ozone $\left(\mathrm{O}_{3}\right)$ as a by-product of coronal discharge of electrons and oxidation of ambient oxygen, with the amount of $\mathrm{O}_{3}$ generated directly proportional to the $\mathrm{mEP}$ power requirements needed to remove particles from the airstream at a desired percentage efficiency. Ambient $\mathrm{O}_{3}$ at certain concentrations is theoretically microbicidal, although this effect was not tested as an aspect of this evaluation. $\mathrm{O}_{3}$ can also be detrimental to human health when inhaled at relatively high concentrations, and the FDA requires $\mathrm{O}_{3}$ output of indoor medical devices to be no more than $0.05 \mathrm{ppm}$ or $50 \mu \mathrm{g} / \mathrm{Liter}$ air. The National Institute of Occupational Safety and Health (NIOSH) recommends an upper limit of $0.10 \mathrm{ppm}(100 \mu \mathrm{g} /$ Liter air $)$, not to be exceeded at any time during an 8-hour workday. The $\mathrm{mEP}$ in this respirator was engineered in a micronized format that provides a high percentage of particle removal at a relatively low power requirement. The preliminary assessment of the mEP using a variety of power requirements showed low $\mathrm{O}_{3}$ production at the power setting that was used in the viral bioaerosol experiments 
$(0.35 \mathrm{mw})$. This design results in the generation of $\mathrm{O}_{3}$ under the FDA limits and NIOSH recommended time weighted average concentrations, although $\mathrm{O}_{3}$ measurement was not performed coincidental to the viral bioaerosol removal evaluation and should be included in future studies.

In summary, results of this evaluation demonstrated approximately equivalent performance in particle removal and viral RNA reduction for both respirators. The mEP respirator successfully demonstrated particle removal and viral removal as a constituent of the bioaerosol without pressure drop to the laboratory-simulated user. The mEP respirator, if further developed, could benefit individuals requiring respiratory protection for long periods of time without the necessity of labored breathing through filter substrate when the use of other respiratory protection such as a powered air-purifying respirator (PaPR) or self-contained breathing apparatus (SCBA) is not available or impractical. The mEP respirator could also be used in circumstances where respiratory protection is required for ambulatory or other compromised individuals that may not be physically able to produce the inspiratory flow required to breathe through filter-based respirators. Future evaluations should investigate many of the aspects that were identified limitations of this study, including the effect of $\mathrm{O}_{3}$ generation upon the efficiency of particle removal, as well as laboratory assessment of the pathogenagnostic mechanism of particle removal for other airborne threats such as influenza. 
Acknowledgements. The authors would like to thank Stephanie Killeen for laboratory coordination of the experiments involving biocontainment, and the resources utilized in these studies associated with the Infectious Disease Aerobiology Scientific Core at the Tulane National Primate Research Center. We thank Angela Birnbaum for reviewing and optimizing all technical SOPs and overseeing the safety of this study.

Funding. This study was supported, in part, by Henley Ion, Inc. and and also supported, in part, by Grant OD011104 from the Office of Research Infrastructure Programs, Office of the Director, NIH.

Conflict of Interest. The authors declare that the research was conducted in the absence of any commercial or financial relationships that could be construed as a potential conflict of interest. Dr. Roy is principal investigator and Tulane University the recepeint of sponsored research funding from Henley Ion, Inc. expressly for research and development activites. Dr. Henley is a paid employee of Henley Ion, Inc. Mr. Hager is an employee of Phase Three Product Development, a contractor to Henley Ion, Inc. 
medRxiv preprint doi: https://doi.org/10.1101/2022.01.27.22269961; this version posted January 28, 2022. The copyright holder for this preprint

(which was not certified by peer review) is the author/funder, who has granted medRxiv a license to display the preprint in perpetuity.

It is made available under a CC-BY-ND 4.0 International license .

\section{References}

1. Khan, S., et al., The emergence of a novel coronavirus (SARS-CoV-2), their biology and therapeutic options. J Clin Microbiol, 2020.

2. Banik, R.K. and A.K. Ulrich, Evidence of short-range aerosol transmission of SARSCoV-2 and call for universal airborne precautions for anesthesiologists during the COVID-19 pandemic. Anesth Analg, 2020.

3. Deng, C.X., The global battle against SARS-CoV-2 and COVID-19. Int J Biol Sci, 2020. 16(10): p. 1676-1677.

4. Fink, J.B., et al., Reducing Aerosol-Related Risk of Transmission in the Era of COVID19: An Interim Guidance Endorsed by the International Society of Aerosols in Medicine. J Aerosol Med Pulm Drug Deliv, 2020.

5. Bartoszko, J.J., et al., Medical Masks vs N95 Respirators for Preventing COVID-19 in Health Care Workers A Systematic Review and Meta-Analysis of Randomized Trials. Influenza Other Respir Viruses, 2020.

6. Zangmeister, C.D., et al., Filtration Efficiencies of Nanoscale Aerosol by Cloth Mask Materials Used to Slow the Spread of SARS-CoV-2. ACS Nano, 2020. 14(7): p. 91889200.

7. Clase, C.M., et al., Cloth Masks May Prevent Transmission of COVID-19: An EvidenceBased, Risk-Based Approach. Ann Intern Med, 2020. 173(6): p. 489-491.

8. Mahase, E., Covid-19: Are cloth masks still effective? And other questions answered. BMJ, 2021. 372: p. n432.

9. Anderson, M.G., Cloth Masks May Prevent Transmission of COVID-19. Ann Intern Med, 2021. 174(4): p. 579-580.

10. Milton, D.K., et al., Influenza virus aerosols in human exhaled breath: particle size, culturability, and effect of surgical masks. PLoS Pathog, 2013. 9(3): p. e1003205.

11. Qaseem, A., et al., Update Alert: Use of N95, Surgical, or Cloth Masks to Prevent COVID-19 in Health Care and Community Settings: Living Practice Points From the American College of Physicians (Version 1). Ann Intern Med, 2020. 173(12): p. 170.

12. Wang, Q., L. Golshahi, and D.R. Chen, Advanced testing method to evaluate the performance of respirator filter media. J Occup Environ Hyg, 2016. 13(10): p. 750-8.

13. Eshbaugh, J.P., et al., N95 and p100 respirator filter efficiency under high constant and cyclic flow. J Occup Environ Hyg, 2009. 6(1): p. 52-61.

14. Scott, A.R., et al., Safety concerns for facial topography customized 3D-printed N95 filtering face-piece respirator produced for the COVID-19 pandemic: initial step is respiratory fit testing. Int J Oral Maxillofac Surg, 2020. 49(12): p. 1660-1661.

15. Or, P., J. Chung, and T. Wong, A novel approach to fit testing the N95 respirator in real time in a clinical setting. Int J Nurs Pract, 2016. 22(1): p. 22-30.

16. Houwink, E.H. and W. Rolvink, The quantitative assay of bacterial aerosols by electrostatic precipitation. J Hyg (Lond), 1957. 55(4): p. 544-63.

17. Park, M., A. Son, and B. Chua, Microorganism-ionizing respirator with reduced breathing resistance suitable for removing airborne bacteria. Sens Actuators B Chem, 2018. 276: p. 437-446.

18. Ivanenko, A.A., et al., Direct and rapid analysis of ambient air and exhaled air via electrostatic precipitation of aerosols in an atomizer furnace and Zeeman spectrometry. Anal Bioanal Chem, 2005. 381(3): p. 713-20. 
medRxiv preprint doi: https://doi.org/10.1101/2022.01.27.22269961; this version posted January 28, 2022. The copyright holder for this preprint

(which was not certified by peer review) is the author/funder, who has granted medRxiv a license to display the preprint in perpetuity.

It is made available under a CC-BY-ND 4.0 International license.

19. Martin, S.B., Jr. and E.S. Moyer, Electrostatic respirator filter media: filter efficiency and most penetrating particle size effects. Appl Occup Environ Hyg, 2000. 15(8): p. 60917.

20. Makowski, K., Deposition and resuspension of selected aerosols particles on electrically charged filter materials for respiratory protective devices. Int J Occup Saf Ergon, 2005. 11(4): p. 363-76.

21. Fears, A.C., et al., Persistence of Severe Acute Respiratory Syndrome Coronavirus 2 in Aerosol Suspensions. Emerg Infect Dis, 2020. 26(9).

22. NIOSH publishes respirator final rule. Occup Health Saf, 1995. 64(7): p. 11.

23. Beddingfield, B.J., et al., Effective Prophylaxis of COVID-19 in Rhesus Macaques Using a Combination of Two Parenterally-Administered SARS-CoV-2 Neutralizing Antibodies. Front Cell Infect Microbiol, 2021. 11: p. 753444.

24. Ghatak, S., et al., Electroceutical fabric lowers zeta potential and eradicates coronavirus infectivity upon contact. Sci Rep, 2021. 11(1): p. 21723. 


\section{Figure legends}

Figure 1. Protoyped mEP respirator. (a) front view, picture. (b) 3-D computer rendering with side panel cover omitted to reveal internal mechanics of particle removal from inspiratory flow, green-colored air flow represents ambient air from inlet into mask; blue-color air flow denoted air with particles removed by the mEP respirator. (c) 3-D computer rendering exploded view of the mEP unit within the mask, promotion of charged electrons, and electrostatic precipitation, and collection plate. (d) analytical determination of power and corresponding particle removal percentage when operated at $85 \mathrm{lpm}$ flow through the respirator inlet. (e) analytical determination of power requirements to endogenous ozone generation by the mEP.

Figure 2. Configuration of exposure system used with SARS-CoV-2 bioaerosol evaluation. The air supply to the system was maintained at >40 PSIG, and at 21 PSIG to the nebulizer (A) which generates $\sim 7$ LPM at that pressure, and dilution air (B) providing auxillary air flow for mixing at 9 LPM. The $16 \mathrm{~L}$ aerosol chamber (C) was operated dynamically with a constant flow of nebulized aerosol particles within the combination flow provided by the nebulizer and dilution air. Each device or filter was housed within the chamber in discrete experiments. An inlet for sampling by the particle counter (D) or AGI aerosol sampler (E) at an exhause flow of either 5 or 6 LPM, respectively, was acutated at separate times and and residual exhaust, or when the sampler was disengaged, provided a complete exhaust flow of 16 LPM (F). The entire system was expertly controlled using the AeroMP automated aerosol exposure system (Biaera). 
medRxiv preprint doi: https://doi.org/10.1101/2022.01.27.22269961; this version posted January 28, 2022. The copyright holder for this preprint (which was not certified by peer review) is the author/funder, who has granted medRxiv a license to display the preprint in perpetuity.

It is made available under a CC-BY-ND 4.0 International license .

Figure 3. Particle counts of viral bioaerosols using the evaluation system within

biocontainment. Counts from the energized mEP significantly reduced aerosol particles by a mean of $96.5 \%$ when compared to ambient (chamber) aerosol content; the N95 filter respirator significantly reduced particles by an approximately equivalent $96.9 \%$ when compared to ambient (chamber) particle content. The HEPA filter essentially removed all particles from the airstream.

Figure 4. Removal of SARS-CoV-2 viral RNA using either the mEP or N95 filter respirator in the aerosol evaluation system within biocontainment. The energized mEP significantly removed an average of $99.792 \%$ SARS-CoV-2 viral RNA from the air when compared to ambient (chamber) viral RNA aerosol concentrations. The N95 significantly removed an average of $99.942 \%$ SARS-CoV-2 viral RNA when compared to ambient (chamber) viral RNA aerosol concentrations. The deenergized mEP removed an insignificant amount of SARS-CoV-2 viral RNA and approximately the ambient (chamber) viral RNA aerosol concentrations. The inline HEPA filter removed essentially all viral RNA from the airstream. 
medRxiv preprint doi: https://doi.org/10.1101/2022.01.27.22269961; this version posted January 28, 2022. The copyright holder for this preprint (which was not certified by peer review) is the author/funder, who has granted medRxiv a license to display the preprint in perpetuity.

It is made available under a CC-BY-ND 4.0 International license .

(a)

(c)
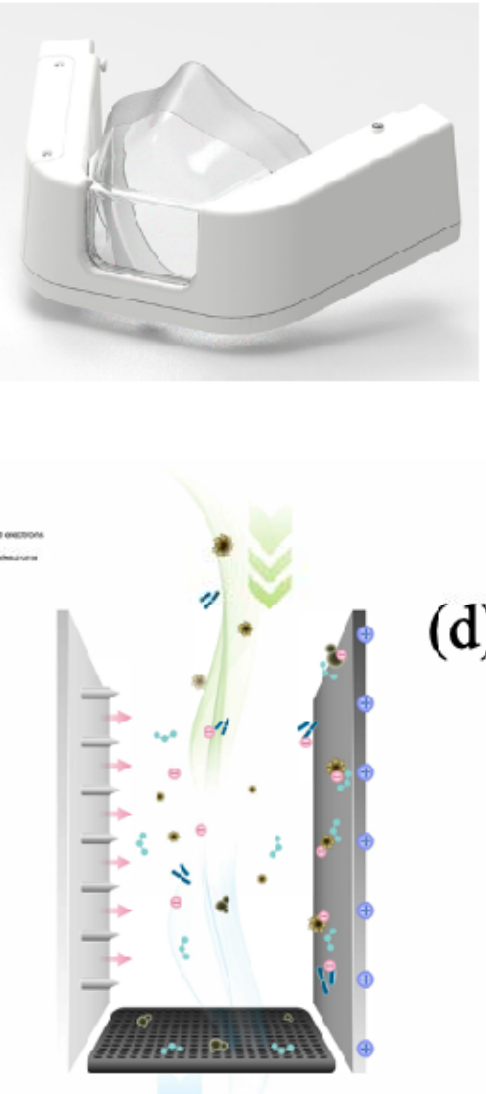

(e)
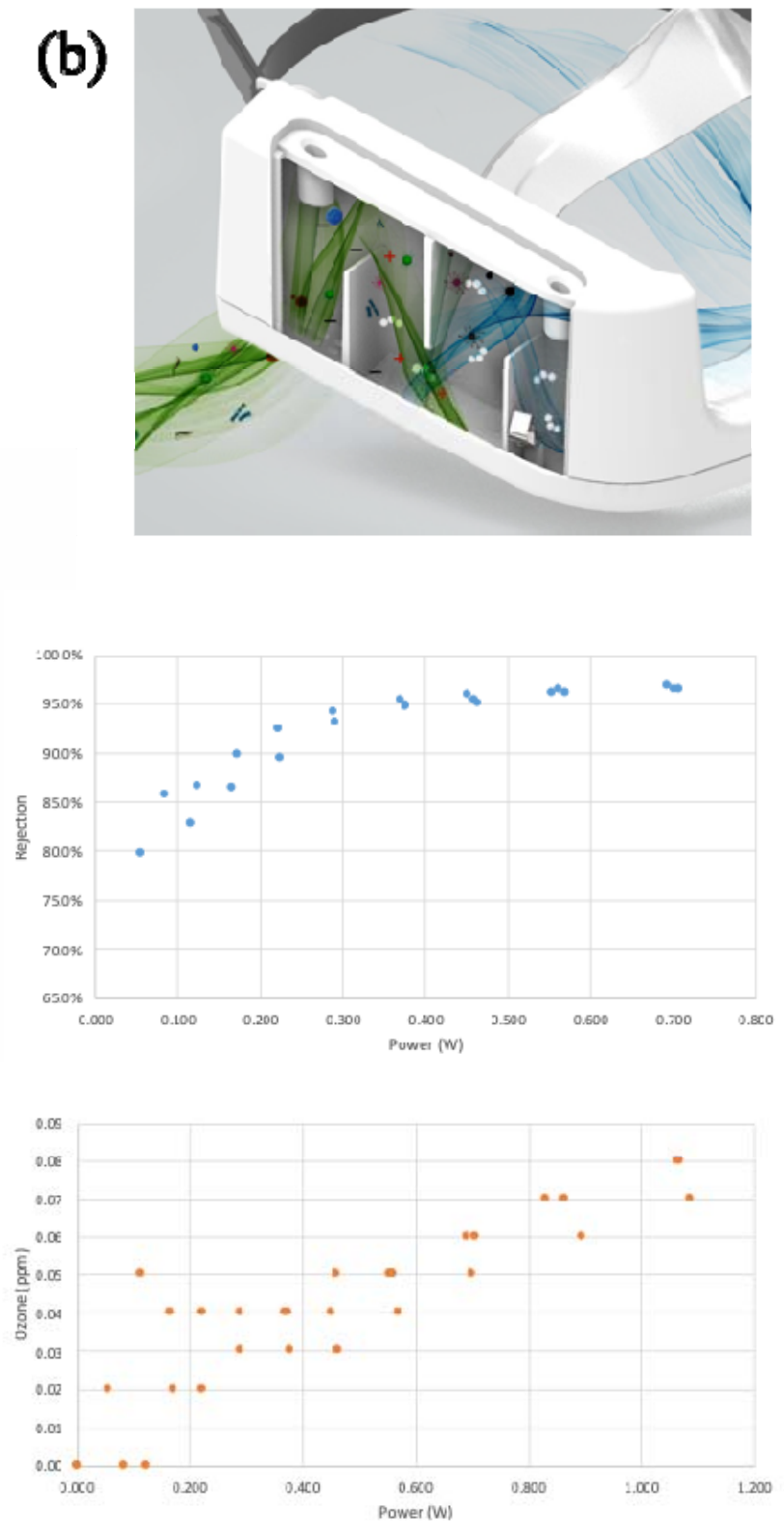

(d)

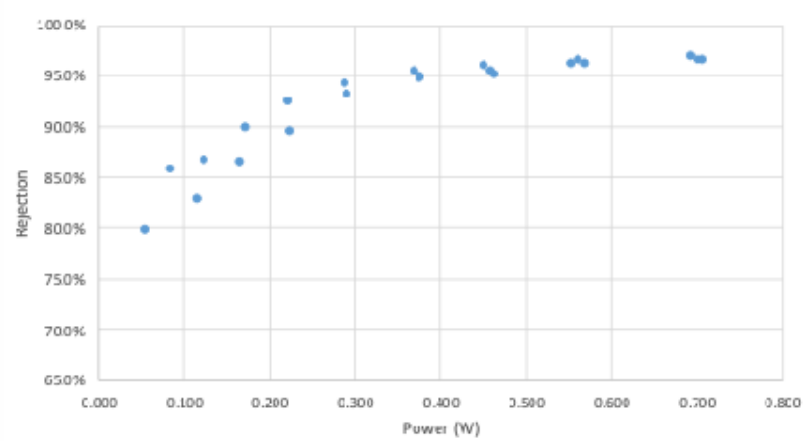

FIGURE 1. 
medRxiv preprint doi: https://doi.org/10.1101/2022.01.27.22269961; this version posted January 28, 2022. The copyright holder for this preprint (which was not certified by peer review) is the author/funder, who has granted medRxiv a license to display the preprint in perpetuity. It is made available under a CC-BY-ND 4.0 International license.

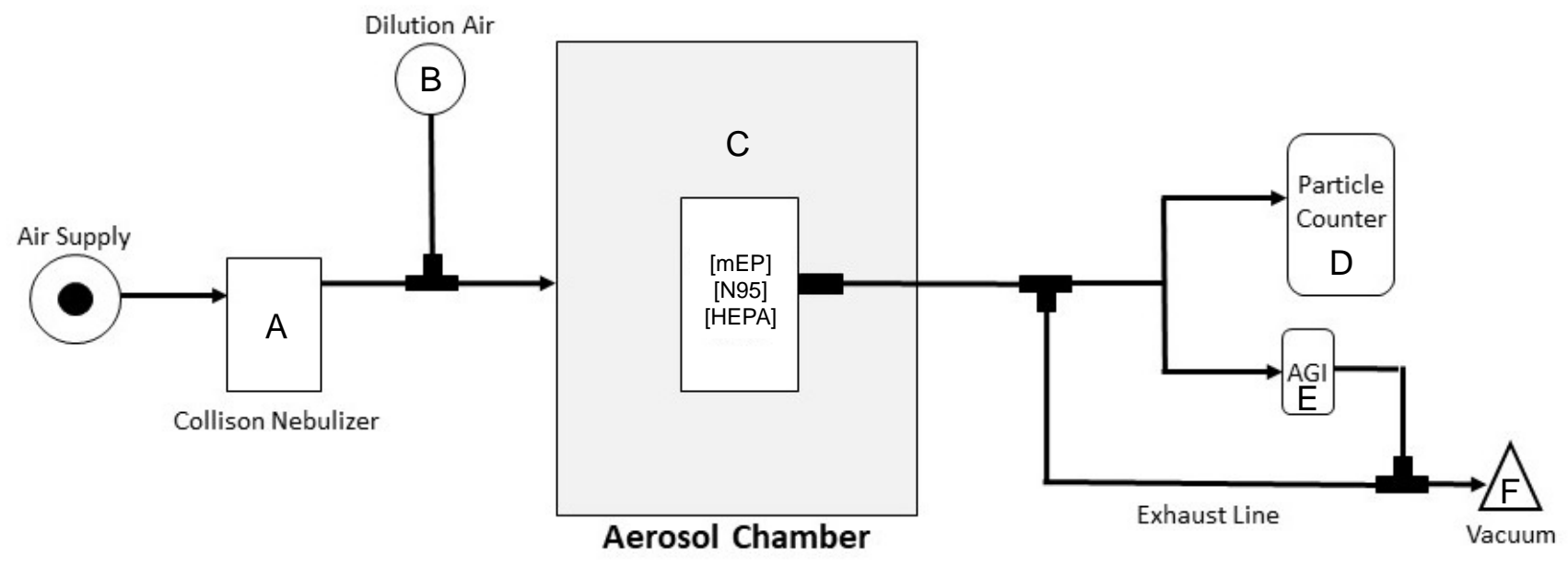

FIGURE 2. 
medRxiv preprint doi: https://doi.org/10.1101/2022.01.27.22269961; this version posted January 28, 2022. The copyright holder for this preprint (which was not certified by peer review) is the author/funder, who has granted medRxiv a license to display the preprint in perpetuity. It is made available under a CC-BY-ND 4.0 International license.

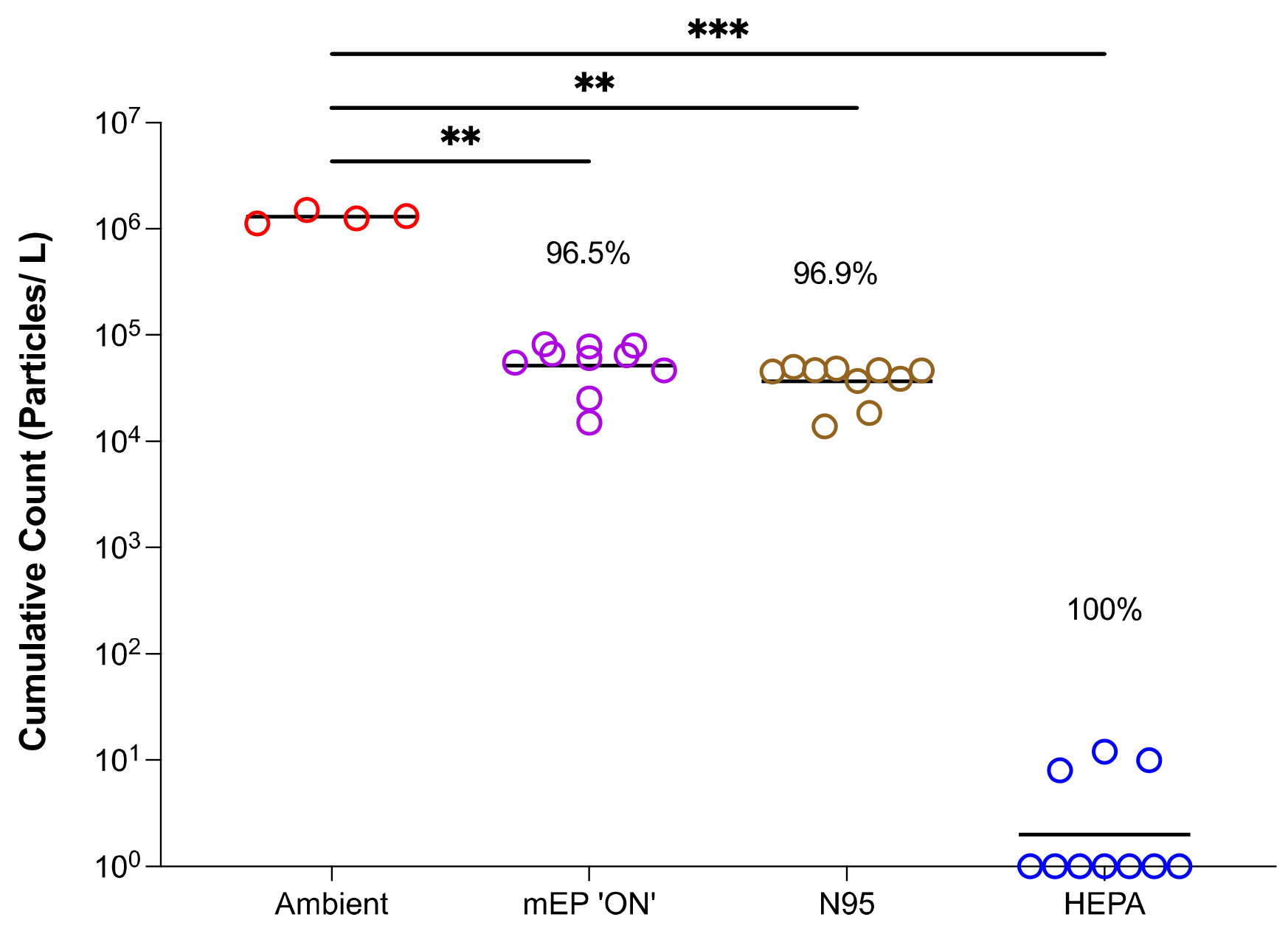

FIGURE 3. 
medRxiv preprint doi: https://doi.org/10.1101/2022.01.27.22269961; this version posted January 28, 2022. The copyright holder for this preprint (which was not certified by peer review) is the author/funder, who has granted medRxiv a license to display the preprint in perpetuity. It is made available under a CC-BY-ND 4.0 International license.

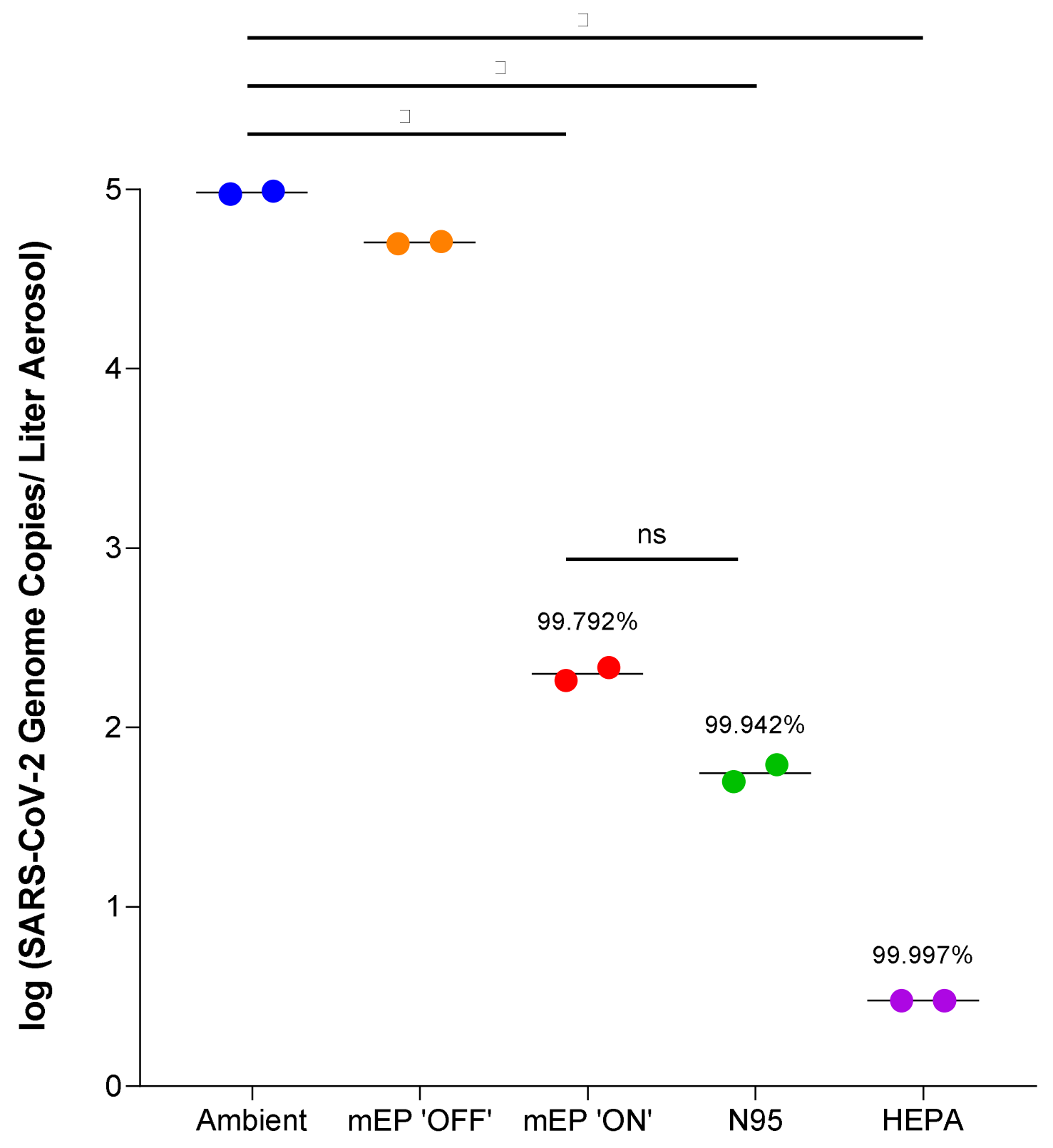

FIGURE 4. 